\title{
ANALISIS PERENCANAAN PEMBANGUNAN DI DESA SUNGAI BERINGIN KECAMATAN RENGAT KABUPATEN INDRAGIRI HULU
}

\author{
PANCA SETYO PRIHATIN*, SURYA AKBAR** \& EFRIONO*** \\ * Mahasiswa Program Study Administrasi Negara Sekolah Tinggi Ilmu Administrasi \\ Indragiri \\ **Dosen Program Study Administrasi Negara Sekolah Tinggi Ilmu Administrasi \\ Indragiri
}

\begin{abstract}
ABSTRAK
Penelitian ini bertujuan untuk mengetahui tingkat keberhasilan perencanaan pembangunan yang ada di Desa Sungai Beringin Kecamatan Rengat Kabupaten Indragiri Hulu, dan untuk mengetahui factor apa saja yang mempengarui keberhasilan pembangunan di desa tersebut. Sumber data diperoleh dengan beberapa cara yaitu Survey, Wawancara, Observasi, Kuisioner. Analisis data menggunakan Model Spradley Domain.

Hasil penelitian ini menunjukan bahwa tingkat keberhasilan program pembangunan yang ada di Desa Sungai Beringin Kecamatan Rengat Kabupaten Indragiri Hulu tergolong tinggi dengan sebagian besar Dana yang didapatkan oleh desa dipergunakan untuk pembangunan didesa berupa insprastruktur jalan Desa serta bangunan untuk kepentingan masyarakat yang ada didesa Sungai Beringin Kecamatan Rengat Kabupaten Indragiri Hulu.

Adapun yang mempengaruhi pelaksanaan program pembangunan yang ada di Desa tersebut yaitu faktor intern yang meliputi kesadaran masyarakat, pendidikan serta penghasilan masyarakat desa dan faktor ekternal yang meliputi Pemerintahan Pusat dan Daerah serta peraturan peraturan yang berlaku yang terkait dengan pembangunan didesa.
\end{abstract}

Kata Kunci : Wawancara, Observasi, Kuisioner, Pembangunan.

\section{ABSTRACT}

This study aims to determine the level of success of the planing of development in the Sungai Beringin Village, Rengat District, Indragiri Hulu Regency, and to find out what factors influence the success of development in the village. Sources of data are obtained in several ways, namely Survey, Interview, Observation, Questionnaire. Data analysis using the Spradley Domain Model.

The results of this study indicate that the success rate of the existing development programs in Sungai Beringin Village, Rengat District, Indragiri Hulu Regency. classified as high with most of the funds obtained by the village being used for development in the village in the form of village road infrastructure and buildings for the benefit of the community in the village of the Beringin River, Rengat District, Indragiri Hulu Regency.

As for those that affect the implementation of the existing development programs in the village, namely internal factors which include community awareness, 
education and income of the village community and external factors which include the Central and Regional Governments as well as applicable regulations related to rural development.

Keywords: Interview, Observation, Questionnaire, Development.

\section{PENDAHULUAN}

Dengan disah kannya UU Nomor 6 Tahun 2014 Tentang Desa, Desa diberi kepercayaan oleh Negara untuk mengatur dan mengelola keuangan dalam rangka pembangunan di desa dengan tetap memperhatikan peraturan yang berlaku. Harapan membawa desa menjadi lebih maju, mandiri, demokratis dan sejahtera akan terbuka lebar. Desa tidak lagi menjadi objek pembangunan dan pemerintah desa bersama masyarakat akan berperan aktif untuk menjadi desa yang kuat. Desa adalah desa dan desa adat atau yang disebut dengan nama lain, selanjutnya disebut Desa, adalah kesatuan masyarakat hukum yang memiliki batas wilayah yang berwenang untuk mengatur dan mengurus urusan pemerintahan, kepentingan masyarakat setempat berdasarkan prakarsa masyarakat, hak asal usul, dan/atau hak tradisional yang diakui dan dihormati dalam sistem pemerintahan Negara Kesatuan Republik Indonesia. (UU nomor 6 tahun 2014 tentang desa, pada Bab I pasal 1).

Pemerintah pada tanggal tangal 15 Januari 2014 telah menetapkan UndangUndang Nomor 6 Tahun 2014 Tentang Desa. Dalam konsideran Undang- Undang tersebut disampaikan bahwa Desa memiliki hak asal usul dan hak teradisional dalam mengatur dan mengurus kepentingan masyarakat setempat dan berperan mewujudkan citacita kemerdekaan berdasarkan UndangUndang Dasar 1945. Dengan ditetapkannya Undang- Undang Nomor 6 Tahun 2014 Tentang Desa diharapkan dapat membawa paradigma baru tentang pembangunan, mampu mengubah cara pandang pembangunan, kesejahteraan ekonomi tidak hanya berada dikota namun menyebar sampai kepelosok Desa. Sehingga didalam pembangunan Negara Republik Indonesia dimulai dari Desa. Sebenarnya gagasan untuk melahirkan Undang-Undang Desa Nomor 6 tahun 2014 yang disyahkan pada tanggal 15 Januari 2014, adalah sebuah proses kegelisahan para pemimpin bangsa ini, walau sebelum dan sesudah lahirnya UU DESA tersebut banyak menuai perdebatan dan kontrovensi dikalangan berbagai pihak dan elit. Dan itu adalah buah pikir dari kepedulian kita dalam menata dan mengurus tetapi bukan menguras bangsa ini. Undang-Undang Desa lahir dengan semangat Demokrasi yang harus dibangun dari masyarakat, dan komunitas masyarakat itu berada diwilayah Desa.

Bergulirnya UU DESA dengan memberikan bantuan langsung keuangan negara yang ter-implementasi melalui Dana Desa, yang mana Dana Desa telah ter-anggarkan melalui skema APBN, yang dileading oleh Kementerian Desa dan PDTT, tentu dengan seperangkat regulasi yang telah di keluarkan oleh Kemendes PDTT, ini dinilai sangat tepat dalam memberikan solusi konkrit terkait persoalan pembangunan, tidak hanya pembangunan dibidang fisik (infrastruktur) saja, tetapi pembangunan yang menukik pada peningkatan kapasitas sumber daya manusia (SDM) pengelolanya, dan bagaimana komunitas. ditingkat tapak mampu mengelola sumber daya desanya, dengan jumlah 74.754 Desa. (Peraturan Menteri Dalam Negeri Nomor 56 Tahun 2015 tentang Kode dan data wilayah Administrasi pemerintahan) disebutkan bahwa jumlah Desa dan kelurahan di Indonesia adalah 83.184 
(74.754 Desa +8.430 Kelurahan) yang tersebar di Indonesia dengan memiliki keberagaman pengetahuan inovasi dan keunikan tersendiri di tingkat desa. Sejak tahun 2014 - 2018 desa telah disugukan dengan Membuminya Undang - Undang Desa No. 6 tahun 2014 tentang Desa. Dan ini memberikan effect positif yang sangat baik bagi pemerintah provinsi, kabupaten, dan terutama desa.

Pembangunan bangsa selama ini dengan sistem sentralistik dan top down oleh banyak kalangan dipandang sebagai sistem yang telah menciptakan kegagalan dan ketergantungan bagi masyarakat. Implementasi selama ini seakan mengeksploitasi sumber daya masyarakat yang telah mendiskreditkan masyarakat khususnya masyarakat desa. Berbagai persoalan muncul seperti ketidak adilan, ketidakmerataan atau kesenjangan pembangunan yang kurang memberikan ruang eksplorasi sumber daya lokal sehingga kehadiran UU desa no 6 tahun 2014 merupakan sebuah regulasi bangsa yang mencoba untuk mendesain pembangunan desa berbasis kearifan lokalnya. Kebebasan perlu ditegakan supaya wajah pembangunan tetap beradab dan berprikemanusiaan. Menjamin kebebasan individu berarti mencegah masyarakat dari kemungkinan tumbunya kekuasaan tirani atau kebijakankebijakan pembangunan semena -mena yang hendak menukar modernisasi dengan harkat dan martabat warga Negara. (M. AMIEN RAIS.173.1990).

Untuk itu UU Desa No 6 Tahun 2014 adalah sebuah bentuk pengakuan yang melegitimasi posisi dan kedudukan desa dan komunitasnya berdasarkan hak asul usulnya sekaligus mendorong perubahan desa sebagai sebuah identitas ke arah kemajuan. Walau demikian kehadiran UU desa disatu sisi menjadi suatu harapan tetapi disisi lain menjadi sebuah tantangan yang mesti dibangun dalam sebuah sinergisitas yang kolaboratif antar elemen masyarakat guna mencapai visi dan misi kemandirian dan kesejateraan masyarakat. Berangkat dari gambaran singkat tersebut diatas, UU desa no 6 tahun 2014 memiliki sejumlah prospek yang cukup inspiratif sekaligus reflektif dalam menjawab mimpi dari visi dan misinya baik diranah konseptual maupun praksis implementatifnya. Dalam menjawab pertanyaan besar bagaimana prospek kemajuan pembangunan desa ditengah pelaksanaan UU No 6 tahun 2014 tentang desa yang kini berpihak pada desa. Pertanyaan besar ini akan dijawab dalam sebuah kolaborasi pemahaman penulis tentang berbagai amanat UU No 6 tahun 2014 tentang desa. Berbicara tentang undang undang tersebut, jelas terlihat bahwa UU tersebut memberikan peluang bagi otonomi desa. Beberapa keistimewaan dari UU ini antara lain: pengalokasian dana miliaran rupiah ke desa dari APBN dan APBD, Penghasilan kepala desa dan aparat desa, Kewenagan kepala desa, masa jabatan Kepala desa yang bertambah hingga tiga periode, Penguatan fungsi BPD. Dengan mengacu pada paradigma pembangunan yang terkatub dalam UU Desa tersebut diatas, yakni Rekognisi dan asas subsiadiritas maka kehadiran UU desa no 6 tahun 2014 memberikan pengakuan kepada desa berdasarkan hak asal usul desa.

Pengakuan akan otonomi desa sebenarnya telah ada sejak diterapkannya UU Nomor 5 Tahun 1979 Tentang Pemerintahan Desa. dan UU Nomor 22 Tahun 1999 tentang Pemerintahan Daerah. otonomi desa saat itu seakan tumbuh kembali namum tidak diimplementasikan secara lebih spesifik. Saat itu otonomi desa justru mengalami penyusutan akibat adanya ekspansi otonomi daerah. Semakin luas hak mengatur dan mengurus yang dikembangkan pemerintah daerah atas nama hak dan kewajiban otonomi, bersamaan dengan itu menyusut pula makna otonomi desa. Desa 
menjadi powerless, kehilangan kewenangan sekalipun secara ekpslisit dikatakan memiliki otonomi asli. Kini desa melalui Undang-Undang Nomor 6 tahun 2014 muncul kembali dan semakin eksplisit dengan mendasar pada dua pendekatan yaitu Rekognisi dan subsiadiritas. Kehadiran UU desa ini setidaknya ingin menjawab dua problem utama, yaitu mengembalikan otonomi asli desa, serta pada saat yang sama mengembangkan otonomi desa untuk membatasi intervensi otonomi daerah pasca reformasi.

Desa dan atau nama lain berhak mengatur dan mengurus urusannya masing-masing berdasarkan hak asal usul yang diakui dan dihormati oleh negara berdasarkan amanah konstitusi (pasal 18b ayat (2) UUD Republik Indonesia 1945) Bahkan lebih dari itu masa ini memberi tempat bagi tumbuhnya desa adat diluar desa administratif. Terhadap persoalan kedua tampak bahwa desa diharapkan mampu mengembangkan otonomi aslinya untuk membatasi kuasa otonomi daerah yang mengancam hingga ke pori-pori desa dalam praktek sebelumnya. Beberapa prospek pembangunan melalui UU No 6 tahun 2014 bagi desa dalam implementasinya ialah, Melalui kewenangan yang diberikan kepada desa, maka kreativitas dan inovasi akan menjadi lebih menggelora karena didasari adanya demokratisasi desa dengan sedikit meninggalkan intervensi supra desa.

Dengan kewenangan yang demikian serta dukungan dana desa maka desa dalam upaya pelayanan publik dapat menjadi semakin optimal. Dengan demikian prospek lanjutan dari undang undang desa ini akan lebih menghidupkan kondisi atau potensi desa yang selama ini tertidur. Ada banyak potensi desa yang selama ini tertidur yang disebabkan karena kurangya dukungan dana serta mekanisme aturan yang sangat uniformalis sehingga kurang adaptif dan akomodatif terhadap potensi desa. Artinya bahwa dalam mekanisme regulasi yang selama ini terjadi lebih cenderung bersifat umum dan sangat parsial bila dikaji dari persoalan desa per desa.atau sebut saja ada penyeragaman aturan atau regulasi yang bersekala nasional dan regional.

Dalam pelaksanaan pembangunan desa, dari kategori desa seperti desa administratif dan desa adat sebenarnya sebuah konfigurasi sistem yang sangat relevan karena desa adat yang diamanatkan secara tidak langsung negara telah mengakui akan hak asal usulnya. Sederetan nilai dan spiritualitas adat yang kini masih kuat di tingkat desa menjadi lebih hidup kembali sekaligus menjadi pilar yang menopang proses pembangunan dan pelayanan publik. Di beberapa daerah seperti DI NTT,Di Papua atau di daerah lain masyarakatnya masih kuat dengan tradisi budaya serta nilainilai lokal yang terkandung di dalamnya. Ada nilai kebersamaan, solidaritas, toleransi serta kekeluargaan juga strukturstruktur sosial lokal yang masih memiliki pengaruh yang kuat akan menjadi lebih diberdayakan. Dengan memberikan kewenangan kepada desa, maka sebenarnya prospek lain yang juga akan muncul ialah adanya kesadaran kolektif komunitas yang merasa memiliki dan menghargai dalam proses pembangunan.

Selama ini pembangunan desa yang di desain dari atas telah membuahkan kerapuhan sistem sosial. Banyak fenomena yang muncul ialah keberpihakan kepada desa melalui daerah atau sekelompok dari luar disatu sisi mendorong perubahan desa tetapi disisi lain telah memboncengi kepentingan luar yang didominasi oleh sejumlah elemen. Misalnya pemerintah daerah, politikus dan sebagainya.dengan kewenangan dan alokasi dana desa ini secara tidak langsung telah meminimalisir ketergantungan desa terhadap pemerintahan supra desa khususnya di daerah, sekaligus memangkas rantai politik dewasa ini yang notabene money 
politik terselubung melalui sejumlah program pendanaan atau modal. Ada banyak program yang turun ke desa menjelang pemilihan umum dengan harapan akan mendapatkan dukungan konstituen atau adanya program dana aspirasi dewan legislatif misalnya. Hal ini akan memicu persoalan transparansi, akuntabilitas serta memandang desa sebagai basis politik dengan cara politisasi dan sebagainya. Dalam konteks rekognisi refleksi atas kondisi ini secara lebih mendalam, mengungkapkan rekognisi dimaksudkan untuk mengakui dan menghormati identitas, adat istiadat,serta pranata dan kearifan lokal sebagai bentuk tindakan keadilan.

Dengan demikian orientasi uang telah merubah mindset masyarakat sehingga apapun bentuk kegiatan yang menghendaki partisipasi selalu dituntut dengan uang. Masyarakat sudah terkontaminasi dan tergantung dengan uang. Akibatnya modal sosial masyarakat menjadi luntur walaupun uang adalah hal yang memang harus dimiliki. Dengan diberlakukan UU no 6 tahun 2014 yang mengamanatkan kewenangan kepada desa untuk mengatur dan mengontrol desanya sendiri barangkali menjadi suatu prospek konstruktif untuk membangun kembali kekuatan kekuatan desa seperti modal sosial. Modal sosial menjadi sumber utama terlaksananya pembangunan desa. Hal ini diperkuat lagi dengan desa adat dan prinsip pembangunan berbasis kearifan lokal. Artinya bahwa dengan kewenangan diserahkan kepada desa serta pengakuan atas hak asal usul desa memungkinkan desa dapat menghidupkan kembali prinsip pembangunan di desa dengan mengacu pada tuntutan administrasi, tuntutan kearifan lokalnya. Walaupun demikian prospek pembangunan kedepan dalam semangat UU No 6 tahun 2014, sejumlah tantangan mesti juga ditelusuri guna menemukan sebuah upaya antisipatif dan solusi, sehingga kedepannya dapat dilakukan upaya - upaya prefentif.

Dalam Perealisasian UU Nomor 6 Tahun 2014 Tentang Desa juga mempunyai Tantangan dan Hambatan antara Persoalan Sumber Daya Manusia: persoalan pendidikan yang rendah serta minimnya Persoalan sumber daya manusia aparatur desa dalam memahami undang-undang desa serta penjelasan tentang undang undang desa masih sangat minim. Selain itu pengetahuan tentang manajemen kepemimpinan, pola dan pendekatan serta strategi pembangunan dan persoalan lain yang mempengaruhi seperti persoalan politik yang kadang mempolitisasi desa. Sementara itu fenomena pengalaman sistem pembangunan dari masa orde baru hingga masa reformasi saat ini masih kuat dalam memori masyarakat desa. Fenomena tersebut seperti adanya presepsi bahwa program pemberdayaan masyarakat masih dipandang sebagai sebuah proyek yang berujung pada uang. Persoalan dilematis yang lain ialah hilangnya kepercayaan masyarakat atas pengalaman umum adanya kasus korupsi serta merosotnya moralitas pemimpin atas komitmen transparansi dalam pelayanan publik. Faktor keteladanan dan panutan menjadi salah satu faktor penentu partisipasinya masyarakat dalam pembangunan.

Disisi lain tantangan datang dari adanya sistem pembangunan yang selama ini terkesan top down dan lebih di dominasi oleh elite desa, walaupun banyak pihak yang mengatakan reformasi telah merubah tatanan pemerintahan tetapi dilevel desa khususnya desa-desa yang sangat jauh dari kondisi perkotaan, masih sangat nampak. Hal ini berkaitan dengan budaya yang sudah terbentuk selama ini. Faktor berikutnya adalah besarnya kewenangan yang diberikan kepada desa melalui UU no 6 tahun 2014 akan pula memicu persoalan baru. Misalnya dalam UU tersebut walau telah memberi penguatan kepada BPD dalam melakukan 
pengwasan tetapi BPD hanya membahas dan menerima laporan dari masyarakat serta mengawasi kinerja pemerintah desa tanpa adanya suatu ketegasan yang bersifat punisment akan membuka peluang bagi kesewenangan administratif pemerintah desa dalam melakukan ketimpangan. Artinya keterlibatan BPD yang terbatas dan kurang mendetail dalam UU tersebut akan mengurangi sistem kontrol dari masyarakat melalui wakilnya di BPD. Hal ini beralasan sebab di dalam Dalam undang-undang tersebut, BPD berada diluar batasan pengertian pemerintahan desa. sebab pertanggungjawaban akhir tahun anggaran dan akhir masa jabatan kepala desa disampaikan kepada kepala daerah, dan bukan kepada BPD.

Hal lain yang juga menjadi tantangan ialah masa jabatan kepala desa selama 6 tahun dan selama tiga periode. Lamahnya masa jabatan ini baik secara berturut turut maupun tidak akan membuka ruang yang memungkinkan terjadinya kesewenangan. Berbagai persoalan ini menjadi suatu kekuatiran yang akan menjadi tantangan kedepan ketika negara menghendaki adanya otonomi desa. Berdasarkan UndangUndang ini, maka setiap Desa yang ada diseluruh Indonesia akan menerima Alokasi Dana dari Anggaran Pendapatan dan Belanja Negara (APBN) yang bersumber dari belanja Pusat yang disebut dengan Dana Desa atau DD dan tentunya penerimaan setiap desa akan berbeda sesuai dengan kondisi Geografis, jumlah penduduk, jumlah penduduk miskin dan parameter lainnya. Desa yang memiliki hak asal usul dan hak tradisional dalam mengatur dan mengurus kepentingan masyarakat berperan untuk mewujudkan cita- cita kemerdekaan berdasarkan undang- undang dasar Negara Republik Indonesia Tahun 1945 perlu dilindungi dan diberdayakan agar menjadi kuat, maju, mandiri, dan Demokratis sehinggah dapat menciptakan landasan yang kuat dalam melaksanakan pemerintahan dan Pembangunan menuju masyarakat yang adil, makmur dan Sejahterah.

Dalam Penelitian ini akan kita Bahas Permasalahan Pembangunan yang ada pada salah satu Desa yang ada di Kecamatan Rengat Kabupaten Indragiri Hulu yaitu Desa Sungai Beringin yang juga terdampak pada terealisasinya UU Nomor 6 Tahun 2014 Tentang Desa. Dari program pembangunan yang dilaksanakan di Desa Sungai Beringin ini terdapat beberapa kegiatan pembanguan yang kurang ataupun belum menyentuh kepada masyarakat Desa serta belum bisa membawa perubahan kearah yang lebih baik.

Berdasarkan fenomena yang terjadi dilapangan dalam Pelaksanaan pembangunan Desa di Desa Sungai Beringin Kecamatan Rengat Kabupaten Indragiri Hulu sebagaimana yang dikemukakan pada latar belakang masalah diatas maka dapat disimpulkan permasalahan dari penelitian ini adalah : Bagaimana Tahapan- tahapan Perencanaan Pembangunan di Desa Sungai Beringin? dan Apa saja factor yang mempengaruhi Pelaksanaan Pembangunan di Desa Sungai Beringin ? Penelitian ini bertujuan untuk mengetahui tahapan- tahapan Pelaksanaan Pembangunan Desa di Desa Sungai Beringin dan mengetahui factor- faktor yang mempengaruhi Pelaksanaan Pembangunan di Desa Sungai Beringin.

\section{METODE PENELITIAN}

Penelitian ini dilakukan di Desa Sungai Beringin Kecamatan Rengat Kabupaten Indragiri Hulu selama lebih kurang enam Bulan yaitu dari Bulan September Tahun 2018 sampai dengan Bulan Pebruari Tahun 2019. Jenis penelitian ini adalah deskriptif kualitatif. yaitu merupakan salah satu dari jenis penelitian yang termasuk dalam jenis penelitian kualitatif. Adapun tujuan dari 
penelitian ini adalah untuk mengungkapkan kejadian atau fakta, keadaan, fenomena, variabel dan keadaan yang terjadi saat penelitian berlangsung dengan menyuguhkan apa yang sebenarnya terjadi. Penelitian ini menafsirkan dan menguraikan data yang bersangkutan dengan situasi yang sedang terjadi, sikap serta pandangan yang terjadi di dalam suatu masyarakat, pertentangan antara dua keadaan atau lebih, hubungan antar variable yang timbul, perbedaan antar fakta yang ada serta pengaruhnya terhadap suatu kondisi, dan sebagainya. Dalam metode penelitian kualitatif, data dikumpulkan dengan beberapa teknik pengumpulan data kualitatif, yaitu ; Observasi, Wawancara, Dokumentasi. Informan yang di ambil oleh peneliti dalam mengumpulkan Data untuk Skripsi yang ditulis yaitu : Kepala Desa/ Perangkat Desa, Ketua BPD dan beberapa anggota BPD, Beberapa masyarakat desa dengan profesi yang berbeda - beda. Dalam analisis data digunakan teknis analisa data deskriptis yatu data yang dikumpulkan dari objek penelitian dikumpulkan menurut jenisnya dan kemudian ditabulasikan sehingga dapat diungkapkan permasalahannya. Kemudiaan ditelaah dengan teori yang terdapat didalam literature serta diinterpersentasikan dan ditarik kesimpulannya untuk diajukan saransaran perbaikan dimasa yang akan dating.

\section{HASIL PENELITIAN DAN PEMBAHASAN}

Adapun data- data dari indentitas responden yang akan disajikan terdiri dari jenis kelamin, usia dan pendidikan terakhir. Jenis kelamin adalah jenis kelamin dari responden yang telah ditetapkan dalam penelitian untuk mengetahui pengelolaan dana desa dalam upaya pelaksanaan pembangunan di Desa Sungai Beringin Kecamatan Rengat Kabupaten Indragiri Hulu. Usia adalah golongan usia dari responden yang telah ditetapkan dari penelitian untuk mengetahui pelaksanaan dana desa berdarkan Peraturan Bupati Indragiri Hulu Nomor 20 Tahun 2018 Tentang tata cara pembangian dan penetapan rincian Dana Desa setiap Desa di Kabupaten Indragiri Hulu Tahun Anggaran 2018. Tingkat pendidikan adalah golongan tingkat pendidikan dari responden yang telah ditetapkan dalam penelitian untuk mengetahui pengelolaan dana desa dalam upaya pelaksanaan pembangunan di Desa Sungai Beringin Kecamatan Rengat Kabupaten Indragiri Hulu.

Didalam Peraturan Menteri Desa Pembangunan Daerah Tertinggal dan Transmigrasi (Menteri Desa PDTT) Nomor 19 Tahun 2017 Tentang Prioritas Penggunaan Dana Desa tahun 2018 yaitu : Prioritas Penggunaan Dana Desa untuk membiayai pelaksanaan program dan kegiatan di bidang pembangunan Desa dan pemberdayaan masyarakat Desa. Prioritas penggunaan Dana Desa diutamakan untuk membiayai pelaksanaan program dan kegiatan yang bersifat lintas bidang. Program dan kegiatan sebagaimana dimaksud pada ayat (2) antara lain bidang kegiatan produk unggulan Desa atau kawasan perdesaan, BUM Desa atau BUM Desa Bersama, embung, dan sarana olahraga Desa sesuai dengan kewenangan Desa. Pembangunan sarana olahraga Desa sebagaimana dimaksud pada ayat (3) merupakan unit usaha yang dikelola oleh BUM Desa atau BUM Desa Bersama. Prioritas penggunaaan Dana Desa sebagaimana dimaksud pada ayat (1) wajib dipublikasikan oleh Pemerintah Desa kepada masyarakat Desa di ruang publik yang dapat diakses masyarakat Desa.

Melalui alokasi dana desa tentunya desa berpeluang untuk mengelolah pembangunan, pemerintahan dan social kemasyarakatan desa secara otonom. Dana desa adalah dana yang diberikan pada desa yang berasal dari 
pemerintahan pusat melalui kas daerah. Dana desa merupakan salah satu dari sumber pemasukan desa selain dari dana perimbangan yang diterima desa dari kabupaten yang disebut dengan alokasi dana desa dan dana yang bersumber dari provinsi yang disebut dengan bantuan keuangan Provinsi untuk desa serta dana bagi hasil pajak dan retribusi pemerintahan kabupaten untuk desa. Didalam Peraturan Pemerintah Nomor 60 Tahun 2014 tentang Dana Desa yang bersumber dari APBN, Pasal 1, ayat 2 Dana Desa adalah Dana yang bersumber dari Anggaran Pendapatan dan Belanja Negara yang diperuntukkan bagi Desa yang ditransfer melalui Anggaran Pendapatan dan Belanja Daerah Kabupaten/Kota dan digunakan untuk membiayai penyelenggaraan pemerintahan, pelaksanaan pembangunan, pembinaan kemasyarakatan, dan pemberdayaan masyarakat. Tujuan dari dana desa pada dasarnya adalah mewujudkan pertumbuhan ekonomi yang inklusif dengan lebih memeratakan pendapatan.

Analisis

Perencanaan

Pembangunan di Desa Sungai Beringin Kecamatan Rengat Kabupaten Indragiri Hulu, ini perlu dilakukan untuk mengetahui bagaimana pengelolaan Dana Desa di Desa ini dalam prespektif Pembangunan. Pergeseran paradigma pembangunan dari pembangunan infrastruktur ke pembangunan ekonomi dan pemberdayaan masyarakat mengharuskan pengelolaan keuangan desa lebih diarahkan kepada pemberdayaan potensi yang dimiliki masyarakat untuk peningkatan kesejahteraan masyarakat. Oleh karena itu, seharusnya pengelolaan Dana Desa lebih difokuskan kepada pemberdayaan masyarakat untuk mendorong kemandirian masyarakat dalam meningkatkan kesejahteraannya.

Pada Tahun Anggaran 2018 ini Desa Sungai Beringin merupakan desa yang memiliki pendapatan total sebesar Rp. 1.447.805.354,- dengan Rician dari beberapa sumber pendapatan yaitu : Pendapatan Dana Desa (DD) dari Pemerintahan Pusat sebesar Rp. 784.426.000,- berdasarkan (Peraturan Bupati Indragiri Hulu Nomor 20 Tahun 2018 Tentang tata cara pembagian Pengalokasian Dana Desa dari Pemerintahan Pusat) Alokasi Dana Desa (ADD) dari Pemerintahan Kabupaten sebesar Rp. 545.531.000,- berdasarkan (Peraturan Bupati Indragiri Hulu Nomor 19 Tahun 2018 Tentang Perubahan kedua atas peaturan Bupati Indragiri Hulu Nomor 93 Tahun 2017 Tentang Pengalokasian Alokasi Dana penetapan rincian Dana Desa setiap Desa di Kabupaten Indragiri Hulu Tahun Anggaran 2018) pendapatan Desa dari Bantuan Keuangan Provinsi Riau sebesar Rp. 100.000.000,- (Peraturan Gubernur Riau Nomor 98 Tahun 2017 Tentang Pedoman Bantuan Keuangan Pemerintah Provinsi Riau kepada Desa.) dan Pendapatan dari Dana Bagi Hasil Pajak dan Retribusi sebesar Rp. 17.848.354,berdasarkan (Peraturan Bupati Indragiri Hulu Nomor 26 Tahun 2018 Tentang Rincian Alokasi Bagian dari Hasil Pajak Daerah dan Retribusi Daerah untuk Desa se-Kabupaten Indragiri Hulu Tahun Anggaran 2018) sehinggah total pendapatan Desa Sungai Beringin pada Anggaran Pendapatan Belanja Desa Murni Tahun Anggaran 2018 sebesar Rp. 1.447.805.354,- oleh karena waktu yang tidak memungkinkan jadi focus peneltian yang akan kita lakukan hanya pada dana desa yang bersumber dari pemerintahan pusat saja.

Penggunaan dana desa terdiri dari empat bidang yaitu : Bidang Penyelenggaraan Pemerintahan Desa, Bidang Pembangunan Desa, Bidang Pembinaan Kemasyarakatan dan Bidang Pemberdayaan Masyarakat. Sedangkan dilihat dari tingkat kemiskinan di Kecamatan Rengat Desa Sungai Beringin 
merupakan desa yang memiliki jumlah penduduk miskin sebanyak 76 RTM penerima beras miskin, selain faktor banyaknya penduduk miskin di Desa besarnya Alokasi Dana Desa yang yang diterima oleh Desa juga dipengaruhi oleh jumlah penduduk Desa, letak geografis dan luasnya wilayah suatu Desa tersebut. Desa Sungai Beringin terdiri dari 6 Dusun yakni memiliki wilayah yang cukup luas yaitu $\pm 4.600 \mathrm{Ha}$ dibandingkan dengan Desa lainnya yang ada di Kecamatan Rengat. Perolehan Dana yang cukup tinggi di Desa Sungai Beringin harusnya mampu dikelola dengan baik oleh pemerintah desa agar mampu meningkatkan kesejahteraan masyarakat Desa Sungai Beringin itu sendiri. Salah satu upaya peningkatan kesejahteraan masyarakat adalah dengan memberdayakan potensi yang dimiliki masyarakat untuk dikembangkan menjadi lebih baik, agar masyarakat bisa mandiri dan mampu meningkatkan kesejahterannya secara mandiri tanpa harus selalu mengharapkan bantuan dari Pemerintah. Dalam rangka pengoptimalan pengelolaan dana desa dalam pembangunan di desa haruslah melibatkan partisipasi masyarakat dalam setiap tahapnya baik dalam tahap perencanaan, pelaksanaan, hingga tahap pengawasan. Pelibatan partisipasi masyarakat dalam setiap tahap tersebut bertujuan agar masyarakat paham dengan apa yang mereka butuhkan dan apa yang akan mereka lakukan untuk meningkatkan kesejahteraan. Pada bab ini penulis akan memaparkan hasil analisis penelitian yang dilakukan dengan metode wawancara dan observasi tentang analisis pengelolaan Dana Desa di Desa Sungai Beringin dalam Pembangunan Desa. Analisis Pelaksanaan Pebangunan di Desa Sungai Beringin dilihat dari empat tahapan pengelolaan yakni perencanaan (planning), pengorganisasian (organizing), pengarahan atau pelaksanaan (actuating), dan pengawasan (controlling).

Perencanaan adalah sebuah proses yang penting dan menentukan keberhasilan suatu tindakan. Perencanaan merupakan tahap awal dari berjalannya suatu kegiatan, sehingga perencanaan harus dilakukan dengan matang agar kedepannya kegiatan yang direncanakan dapat berjalan dengan efektif. Perencanaan yang merupakan awal berjalannya pengelolaan Dana Desa harus direncanakan dengan baik dan menjadi hal urgent dan pemilihan suatu kegiatan yang menjadi prioritas dalam pengelolaan dana desa. manusia adalah unsur manajemen yang terpenting dalam setiap organisasi. Fungsi-fungsi pokok manajemen menurut George R. Terry yang membentuk fungsi manajemen sebagai salah satu proses sebagai berikut :

Planning, Organizing, Actuating, Controlling. Pengelolaan Dana Desa di Desa Sungai Beringin dalam kaitannya dengan perencanaan pembangunan pastilah dipengaruhi banyak faktor. Dalam penelitian ini melakukan analisis faktor yang mempengaruhi pengelolaan dana desa dari empat faktor yakni Kepemimpinan, Sumber Daya Manusia (SDM) Pengelola Keuangan, Manajemen Pengelolaan dan Partisipasi Masyarakat.

\section{KESIMPULAN}

Berdasarkan hasil penelitian yang telah penulis lakukan, maka dapat ambil suatu kesimpulan bahwa : Pengelolaan dana desa dalam Pelaksanaan Pembangunan di Desa Sungai Beringin Kecamatan Rengat Kabupaten Indragiri Hulu Tahun Anggaran 2018 sudah terlaksana dengan baik. Tetapi bidang yang lain seperti Bidang Pemberdayaan dan Pembinaan Masyarakat masih belum dapat perhatian dari pemerintahan desa yang diamanatkan dalam Permendes Nomor 19 Tahun 2017 tentang Prioritas Penggunaan Dana Desa Tahun 2018. Dalam BAB III Pasal 4. Dana desa 
sebagian besar masih dugunakan untuk pembangunan Infrastruktur sehingga tidak berpengaruh kepada peningkatan taraf kehidupan dan perekonomian masyarakat desa Serta tidak dapat menjadikan sebagai Pendapatan Asli Desa (PAD).

\section{DAFTAR PUSTAKA}

Buku :

Nugroho dan Rochmin Dahuri, 2004, Pembangunan Wilayah. Perspektif Ekonomi, Sosial dan Lingkungan. Jakarta:

Prof. Dr. Inu Kencana Syafiie, M.Si dan Welasari, SIP., M.Si. 2014. Ilmu Administrasi. Pustaka Pelajar : Jogyakarta Riyadi dan Deddy Supriyadi Bratakusumah, 2005. Perencanaan Pembangunan Daerah. Strategi Menggali Potensi dalam Mewujudkan OTONOMI DAERAH. Gramedia Pustaka Umum. Jakarta:

Siagian, S.P., 1994, Manajemen Modern: Bunga Rampai, CV. Masagung, Jakarta.

Kartasasmita, Ginandjar, 1997 Administrasi Pembangunan: Perkembangan Pemikiran dan Praktiknya di Indonesia, LP3ES, Jakarta.

Siagian, S.P., 2008. Administrasi Pembangunan : Konsep, Dimensi, dan Strateginya. Penerbit PT Bumi Aksara : Jakarta.

Tikson, Deddy, 2005. Keterbelakangan dan Ketergantungan, Teori Pembangunan di Indonesia, Malaysiah dan Thailand. Ininnawa, Makassar.

Undang - Undang :

UU Dasar Negara RI 1945 pasal 18 ayat 7,2

UU Nomor 5 Tahun 1979 Tentang Pemerintahan Desa.

UU Nomor 22 Tahun 1999 tentang Pemerintahan Daerah.
UU Nomor 6 tahun 2014 tentang desa

Peraturan :

Peraturan Pemerintah Nomor 60 Tahun 2014 tentang Dana Desa yang bersumber dari APBN, Pasal 1, ayat 2

Peraturan Menteri Dalam Negeri Nomor 56 Tahun 2015 Tentang kode dan data wilayah administrasi Pemerintahan

Permendes Nomor 19 Tahun 2017 tentang Prioritas Penggunaan Dana Desa Tahun 2018. Dalam BAB III Pasal 4

Peraturan Gubernur Riau Nomor 98 Tahun 2017 Tentang Pedoman Bantuan Keuangan Pemerintah Provinsi Riau kepada Desa.

Peraturan Bupati Indragiri Hulu Nomor 19 Tahun 2018 Tentang Perubahan kedua atas peaturan Bupati Indragiri Hulu Nomor 93 Tahun 2017 Tentang Pengalokasian Alokasi Dana Desa dalam wilayah Kabupaten Indragiri Hulu.

Peraturan Bupati Indragiri Hulu Nomor 20 Tahun 2018 Tentang tata cara pembangian dan penetapan rincian Dana Desa setiap Desa di Kabupaten Indragiri Hulu Tahun Anggaran 2018

Peraturan Bupati Indragiri Hulu Nomor 26 Tahun 2018 Tentang Rincian Alokasi Bagian dari Hasil Pajak Daerah dan Retribusi Daerah untuk Desa seKabupaten Indragiri Hulu Tahun Anggaran 2018)

Website :

Alexander 1994/ Portes 1976 https://www.ruangpintar.com/2016/11/def inisi-pengertian-pembangunan.html

Profil Desa Sungai Beringin Kecamatan Rengat Kabupaten Indragiri Hulu Tahun 2017. 